\title{
U.S. Geological Survey Arctic Ecosystem Assessments
}

\author{
The U.S Geological Survey (USGS) conducts natural hazard and resource assessments of the Earth's
} ecosystems and the response of those ecosystems to environmental change, human activities, and land use. Arctic regions of Alaska are important for cultural and economic sustainability and host a wide variety of wildlife species, many of which are of conservation and management interest to the U.S. Department of the Interior. The USGS and collaborators provide information about Arctic ecosystems that are used by Arctic residents, management agencies, and industry. This fact sheet describes recent USGS assessments on focal species and important topic areas in the Arctic.

\section{Caribou}

The USGS determined that despite the longterm presence of energy development within the Central Arctic Herd summer range, female caribou (Rangifer tarandus) had avoidance

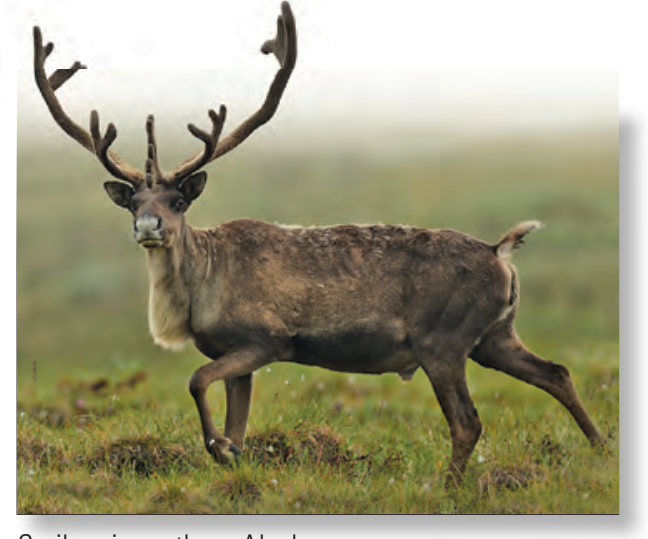

Caribou in northern Alaska.

responses to oil development infrastructure during summer.

Caribou avoided infrastructure during the calving, post-calving, and mosquito-harassment time periods, although effects waned across the season. Caribou reduced their use of habitat within 5 kilometers $(\mathrm{km})$ of development during the calving period, within $2 \mathrm{~km}$ during the post-calving period, and within $1 \mathrm{~km}$ during the mosquito-harassment period. These findings corroborate a growing body of evidence suggesting that habituation to industrial development by caribou in the Arctic is likely to be weak or absent, and emphasize the value of minimizing the footprint of infrastructure within important seasonal habitat to reduce behavioral effects on caribou.

\section{Migratory birds}

Oil development on the Arctic Coastal Plain of Alaska may have negative effects on Arctic-nesting birds. The USGS estimated that human foot traffic reduced survival of white-fronted goose (Anser albifrons) nests by 7-35 percent. In contrast, indirect construction noise, vehicular traffic, and low-flying aircraft did not affect the behavior of nesting geese, highlighting the importance of minimizing direct disturbance effects in breeding areas. Buffer zones in areas of industrial development have been established around nest sites of other species, such as yellow-billed loons (Gavia adamsii), that are sensitive to disturbance. The USGS estimated that these nest site buffers corresponded well with loon movements during nesting not only for yellow-billed loons, but also for red-throated loons (G. stellata) and Pacific loons (G. pacifica) in Arctic Alaska.
The USGS estimated the distribution, abundance, and population trend of 20 breeding waterbird species using 25 years (1992-2016) of aerial survey data collected by the U.S. Fish and Wildlife Service on the Arctic Coastal Plain of Alaska. Important areas for birds included coastal areas near Teshekpuk Lake, the Colville River Delta, and Admiralty Bay; the National Petroleum Reserve in Alaska (NPR-A) was an important area for all species examined. Annual population growth rates over the 25 -year survey period were variable - 13 increased, 6 were stable, and 1 decreased (the red-throated loon). The USGS also observed shifts in breeding distribution for nearly all species, suggesting that waterbirds are responding to changes in local habitat conditions that may be driven by warming temperatures.

\section{Pacific walrus}

To minimize the effects of disturbance on Pacific walruses (Odobenus rosmarus divergens), management agencies need information about population size and locations of seasonal walrus haulouts. In fall, when sea ice retreats from parts of the Chukchi Sea, large numbers of adult female and juvenile walruses form coastal haulouts. Trampling injuries can result in the death of young walruses at these locations when the animals are disturbed. The USGS summarized information dating back to 1852 on Pacific walrus haulouts in a georeferenced database that is available to the public and used to produce maps and other visual tools. Additionally, the USGS assessed walrus popula-

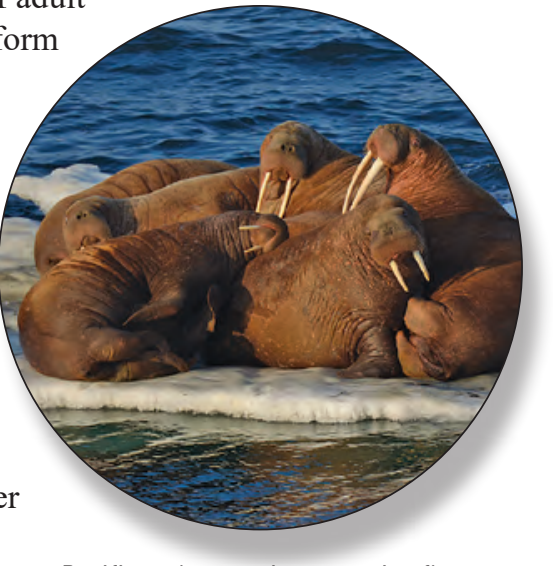

Pacific walrus resting on an ice floe. tion dynamics by synthesizing information on population size, age structure, reproductive rates, and harvest for 1974-2015. This assessment found that the population underwent a multidecade decline, which began to lessen in the 1990s, and that the population decline may have ended by 2015 . 


\section{Polar bears}

The most influential driver affecting the future status of polar bears (Ursus maritimus) is the availability of sea ice, which bears use for feeding, mating, and denning. Diminished sea ice has reduced the overall abundance of Alaska's southern Beaufort Sea polar bear subpopulation and created a growing reliance on land for maternal denning. The USGS estimated that the abundance of polar bears in the Alaska part of the southern Beaufort Sea subpopulation declined from about 1,300 bears in 2003 to

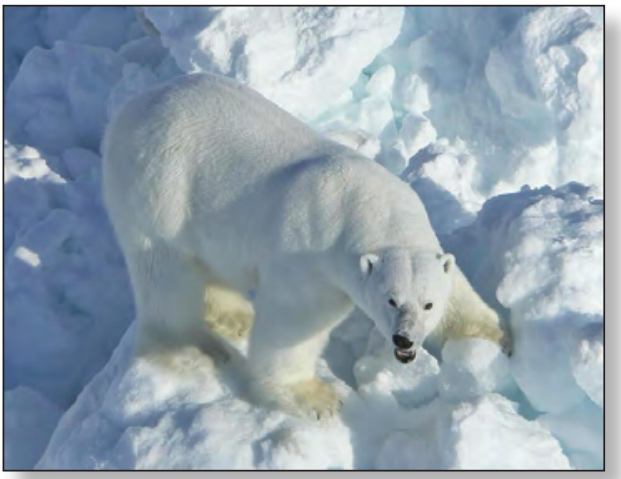

Polar bear in the southern Beaufort Sea.
525 bears in 2006. The number of bears in this area remained generally stable from 2006 to 2015 . The USGS also estimated that more than one-half of the total number of annual polar bear dens (66 of 123) produced by the entire subpopulation were landbased in northern Alaska. Most land-based dens were located between the Colville and Canning Rivers, which includes the Prudhoe Bay-Kuparuk industrial footprint, followed by the 1002 Area of the Arctic National Wildlife Refuge and the NPR-A.

\section{Biosurveillance}

Elevated seawater temperatures are linked to the development of harmful algal blooms (HABs) that produce toxins that can injure or kill wildlife. Since 2015, widespread seabird die-off events, co-occurring with marine heat waves, have been observed annually in many ecoregions of Alaska. The USGS detected the HAB neurotoxin saxitoxin in association with localized die-off events, including in the Arctic, although starvation was determined to be the primary cause of death. The USGS has found saxitoxin in die-off and healthy seabirds as well as in forage fish and marine invertebrates throughout Alaska coastal waters. The widespread occurrence of algal toxins in the marine food web, combined with insights gained from USGS experimental trials, indicates that HABs should be considered in future assessments of seabird and marine mammal health in the Arctic.

Alaska represents a globally important region for the transmission of avian-origin influenza A viruses (IAVs). Expansive wetlands serve as habitat for numerous bird hosts that travel between four

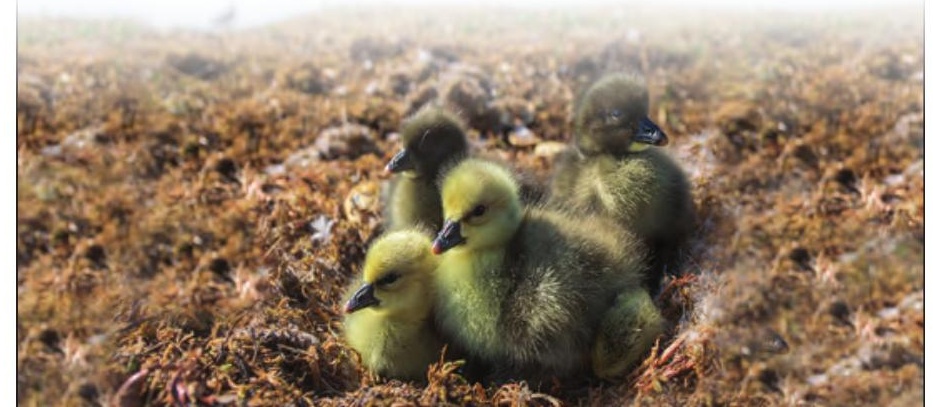

continents during migration. The USGS has repeatedly detected evidence for viral dispersal between East Asia and North America through the sampling of wild birds in Alaska, implying that Alaska is a key point of entry for foreign-origin avian pathogens. Additionally, the USGS has summarized decades of investigations of IAVs in Alaska to inform ongoing and future biosurveillance efforts at the continental scale. The USGS is also conducting biosurveillance for other zoonotic diseases including toxoplasma, tularemia, and brucellosis.

\section{Permafrost}

The USGS has summarized the geographic extent, role, and risks of permafrost thaw to biologic and hydrologic resources in Alaska. Warming permafrost temperatures and longer open water seasons in the Arctic over the past several decades have resulted in accelerated rates of coastal erosion, with rates in some parts of northern Alaska (such as in the NPR-A) as high as 22 meters (about 72 feet) per year. The USGS has reported that coastal changes are altering wetland characteristics and influencing the distribution and abundance of wildlife. Additionally, the USGS has estimated that the amount of mercury stored in permafrost in the Northern Hemisphere is double the amount present in the atmosphere, oceans, and nonpermafrost soils combined and that the release of this mercury from thawing permafrost poses a substantial risk to ecosystem health.

\section{Upcoming Assessments}

More information on existing Arctic ecosystem assessments, including the following upcoming assessments, is available on the USGS Changing Arctic Ecosystems web page:

- Effect of spring phenology on current and future space-use patterns of the Porcupine caribou herd,

- Response of molting black brant geese (Branta bernicla) to helicopter-induced disturbance in the NPR-A,

- Population trends of Pacific walrus and southern Beaufort Sea polar bears from 2015 to the present,

- Effects of marine traffic on Pacific walrus behaviors in the Chukchi Sea, and

- Fall abundance of Pacific walrus in the northeastern Chukchi Sea.

Authors: John M. Pearce and Caroline R. Van Hemert

\section{For more information,}

Director, Alaska Science Center

U.S. Geological Survey

4210 University Drive

Anchorage, Alaska 99508

Photograph credits: Photographs of Pacific black brant in banner, caribou, and Pacific walrus on page 1, and polar bear and snow goose goslings on page 2 provided by U.S. Geological Survey.

Publishing support provided by the U.S. Geological Survey, Science Publishing Network, Tacoma Publishing Service Center 